\title{
Hemofilia pada anjing siberian husky
}

\author{
Langen Tunjungsari*, Bagus I Pradianto \\ Dokter Hewan Praktisi di Klinik Hewan Gloriavet Pet Health Solution, Bandung
}

\begin{abstract}
ABSTRAK: Hemofilia A dan B merupakan gangguan koagulopati pada anjing yang dapat berakibat fatal dan disebabkan oleh adanya defisiensi pada faktor VIII dan faktor IX. Hemofilia merupakan kelainan turunan yang berkaitan dengan kromosom X sehingga gejala klinis timbul pada hewan jantan, sedangkan hewan betina akan berperan sebagai carrier. Kasus hemofilia di Klinik hewan Gloriavet terjadi pada anjing Siberian Husky jantan dengan gejala epistaksis dan hematuria dengan frekuensi yang tinggi. Hasil pemeriksaan darah menunjukkan terjadinya anemia, hemoglobinemia, trombositopenia, dan leukositosis. Pemeriksaan hemostasis didapatkan nilai PT normal dan peningkatan nilai aPTT. Penanganan pertama yang dilakukan adalah tranfusi cairan berupa infus ringer laktat dan asam traneksamat melalui intravena. Akan tetapi hewan mengalami kematian sebelum diberikan terapi lanjutan.
\end{abstract}

Kata kunci:

hemofilia, anjing, siberian husky, transfusi cairan.

\section{- PENDAHULUAN}

Hemofilia merupakan salah satu gangguan koagulopati pada anjing yang bersifat inheritance atau turunan sebagai hasildari adanya defisiensi faktor VIII bagi hemofilia A dan faktor IX pada penderita hemofilia B. Kedua kelainan tersebutsangat berkaitan dengan kromosom $\mathrm{X}$, sehingga gejala klinis akan timbul pada hewan jantan, jarang terjadi pada hewan betina dan biasanya betina akan berperan sebagai carrier (Nielssen 2007). Gejala klinis yang timbul berupa pendarahan yang bersifat spontan dan akan bervariasi pada setiap individu. Gangguan hemofilia telah beberapa kali dilaporkan terjadi pada beberapa ras anjing murni dan juga mongrel. Ras anjing yang paling sering dilaporkan mengalami gangguan hemofilia A diantaranya German shepherd, German shorthaired pointer, dan Siberian husky. Beberapa ras anjing lainnya yang juga pernah dilaporkan antara lain Beagle, Collie, Chihuahua, French bulldog, English setter, Golden retriever, Labrador retriever, Poodle, St. Bernard, Samoyed, Shetland sheepdog, dan Weimaraner. Ras anjing yang paling sering dilaporkan mengalami hemofilia B antara lain Alaskan malamute, American cocker spaniel, Black and tan coonhound, Cairn terrier, Labrador retriever dan St Bernard (Ackerman 2011). Tulisan ini melaporkan kasus hemofilia pada anjing Siberian Husky yang ditangani di Klinik Hewan Gloriavet Pet Health Solution, Bandung.

\section{- KASUS}

Sinyalemen, anamnesa, dan gejala klinis: Seekor anjing Siberian husky dengan jenis kelamin jantan berusia \pm 3 tahun, mengalami pendarahan pada hidung dan mulut, urinasi berdarah (hematuria) yang berulang dengan frekuensi yang tinggi. Anjing terlihat gelisah, suhu anjing $39,8^{\circ} \mathrm{C}$, dan mengalami tachypnea.

Uji pendukung dan diagnosa,: Pemeriksaan darah dilakukan untuk menilai status klinis dari anjing tersebut. Pemeriksaan hemostasis dilakukan dengan menghitung nilai dari PT dan aPTT. Diagnosa untuk kasus ini adalah hemofilia.

Diferensial diagnosa, prognosa dan terapi: Differensial diagnosa dari kasus ini antara lain immune-mediated hemolytic anemia (IMHA), immune-mediated thrombocytopenia (IMT), Disseminated Intravascular Coagulation (DIC). Prognosa hewan terhadap penyakit adalah dubius-infausta. Hewan diberikan penanganan awal berupa infus Ringer Laktat dan pemberian asam traneksamat melalui intravena. Hewan mengalami kematian sebelum diberikan terapi lanjutan.

\section{- HASIL DAN PEMBAHASAN}

Hasil pemeriksaan darah menunjukkan bahwa hewan mengalami anemia, hemoglobinemia, trombositopenia, dan leukositosis (Tabel 1). Hasil tes PT menunjukkan nilai normal dan nilai aPTT mengalami peningkatan. Menurut Nielssen (2007), nilai PT normal dan aPTT yang lebih lama mengindikasikan bahwa hewan mengalami gangguan hemostatik yang diakibatkan oleh adanya defisiensi faktor koagulasi darah.

Kasus hemofilia sangat berkaitan dengan gangguan hemostasis pada tubuh hewan. Menurut Ettinger (2017), hemofilia dengan faktor VIII sebanyak $6-20 \%$ bersifat

Diterima: 05-10-2019 | Direvisi: 31-10-2019 | Disetujui: 05-11-2019 (C) 2019 CC-BY-SA. Ini adalah artikel Open Access yang didistribusikan berdasarkan ketentuan dari Creative Commons Attribution ShareAlike 4.0 International License (https://creativecommons.org/licenses/by-sa/4.0/). 
ringan, tidakakan menyebabkan adanya tendensi terjadinya pendarahan, akan tetapi pada penderita dengan faktor VIII antara 2-5\% akan menunjukkan terjadinya pendarahan yang diakibatkan oleh trauma yang bersifat minor, sedangkan penderita dengan faktor kurang dari $2 \%$ akan mengakibatkan terjadinya pendarahan parah dan dapat menyebabkan kematian.

Tabel 1. Hasil pemeriksaan darah pada anjing

\begin{tabular}{|llll|}
\hline Parameter & Satuan & Hasil & Nilai Normal \\
\hline $\mathrm{Hb}$ & $\mathrm{gr} / \mathrm{dL}$ & 7.3 & $12-18$ \\
$\mathrm{HCT}$ & $\%$ & 22 & $37-55$ \\
$\mathrm{RBC}$ & $10^{6} / \mathrm{mm}^{3}$ & 2.7 & $5.5-8.5$ \\
$\mathrm{MCV}$ & $\mathrm{fL}$ & 77 & $60-77$ \\
$\mathrm{MCH}$ & $\mathrm{pg}$ & 26 & $19.5-26$ \\
$\mathrm{MCHC}$ & $\%$ & 34 & $32-36$ \\
WBC & $10^{3} / \mathrm{mm}^{3}$ & 44.8 & $6-17$ \\
Basofil & $\%$ & 0 & $0-1$ \\
Eusinofil & $\%$ & 1 & $2-10$ \\
Neutrofil & $\%$ & 3 & $0-3$ \\
batang & & & \\
Neutrofilsegmen & $\%$ & 85 & $60-77$ \\
Limfosit & $\%$ & 10 & $12-30$ \\
Trombosit & $10^{3} / \mathrm{mm}^{3}$ & 6 & $164-510$ \\
ALP & $\mathrm{U} / \mathrm{L}$ & 31 & $10-150$ \\
Total Protein & $\mathrm{g} / \mathrm{dL}$ & 7 & $5.1-7.8$ \\
Albumin & $\mathrm{g} / \mathrm{dL}$ & 2 & $2.4-4.3$ \\
Ureum & $\mathrm{mg} / \mathrm{dL}$ & 68 & $7-27$ \\
Creatinin & $\mathrm{mg} / \mathrm{dL}$ & 1.5 & $0.4-1.8$ \\
PT & $\mathrm{detik}$ & 14.6 & $14-19$ \\
aPTT & $\mathrm{detik}$ & 120.8 & $75-105$ \\
\hline
\end{tabular}

Tingkat keparahan pada kasus hemofilia berkaitan dengan aktivitas dan ukuran hewan. Hewan yang memiliki ukuran yang lebih besar dengan aktivitas yang lebih tinggi memiliki kemungkinan untuk menimbulkan gejala klinis yang lebih parah dibandingkan dengan hewan yang lebih kecil dengan aktivitas yang relatif lebih rendah (Nielssen 2007). Gejala klinis dapat bervariasi pada setiap hewan, bergantung kepada lokasi organ yang mengalami gangguan. Menurut Ettinger (2017), gejala klinis pada pasien hemofilia dapat berupa gangguan secara lokal seperti hematoma (seringkali pada area injeksi), pendarahan dengan waktu yang lama setelah trauma atau bedah, pendarahan mukosa, dan kepincangan akibat hemarthrosis. Hal yang serupa dilaporkan juga oleh pada anjing mixedbreed (Jonkisz et al. 2016)

Gejala klinis yang dialami anjing Siberian Husky dalam kasus ini adalah pendarahan pada hidung, mulut dan hematuria dalam waktu lama dan frekuensi tinggi. Penyebab utama munculnya gejala klinis tidak diketahui, akan tetapi kondisi hemofilia yang dialami oleh anjing membuat kondisi anjing semakin buruk dengan pendarahan yang spontan dan hebat. Gambaran pemeriksaan darah menunjukkan bahwa anjing mengalami anemia dan trombositopenia yang disebabkan oleh pendarahan tersebut.

Penanganan kasus hemofilia memiliki tujuan utama untuk menghentikan atau mengurangi pendarahan, baik dengan menggunakan obat-obatan maupun dengan transfusi darah (whole blood/ fresh/ frozen plasma). Menurut (Nielssen 2007), jenis transfusi plasma lebih baik dibandingkan dengan transfusi whole blood karena memiliki lebih sedikit kemungkinan untuk mengalami penolakan atau sensitisasi terhadap sel darah merah. Akan tetapi pada pasien yang mengalami anemia parah sebaiknya diberikan transfusi darah berupa whole blood.

Hemofilia merupakan penyakit yang menurun (Nielssen 2007). Sehingga hewan yang telah diketahui mengalami hemofilia atau berperan sebagai carrier sebaiknya tidak digunakan sebagai indukan maupun pejantan. Hewan yang akan melakukan operasi bedah baik mayor atau minor, khususnya pada ras yang memiliki predisposisi tinggi terhadap kejadian hemofilia, sebaiknya melakukan pemeriksaan PT dan aPTT (Nielssen 2007). Hal ini dimaksudkan untuk mencegah terjadinya pendarahan spontan pada hewan yang mengalami hemofilia. Anjing dengan kelainan koagulasi ini sangat penting untuk didiagnosa sejak dini, sehingga apabila anjing tersebut harus dilakukan operasi, dokter hewan dapat menentukan arah pengobatan dan pencegahan untuk menghindari terjadinya komplikasi baik saat operasi maupun postoperasi.

\section{- SIMPULAN}

Kejadian hemofilia pada anjing dapat berakibat fatal sehingga diperlukan diagnosa dan penanganan yang segera, cepat dan tepat sangat diperlukan. Pengobatan yang dapat dilakukan berupa transfusi darah atau plasma untuk menangani syok hipovolemik.

\section{- INFORMASI PENULIS}

Penulis untuk Korespondensi

*LT: langenlangents@gmail.com

Dokter Hewan Praktisi di Klinik Hewan Gloriavet Pet Health

Solution, Setrasari Plaza C-3, Kota Bandung 40151, INDONESIA

\section{- PUSTAKA ACUAN}

Ackerman L. 2011. The Genetic Connection. USA : AAHA.

Ettinger SJ, Feldman EC, Cote E. 2017. Textbook of Veterinary Internal Medicine $8^{\text {th }}$ Edition. USA : Elsevier.

Jonkisz P, Kurosad A, Sikorska-Kopylowicz A. 2016. Severe Haemophilia A in Mixed-Breed Dog - A Case Report. Research \& Reviews: Journal of Veterinary Sciences. 2(1): 44-46.

Nielssen A. 2007. Coagulopathies. Didalam : Rubin S, Carr A, editor. 2007. Canine Internal Medicine Secrets. USA : Mosby Elsevier. 